\title{
金属材料における原子配列を考慮した 応力および高次応力の微視的表現
}

\author{
安井義 博* 安 井 健 真** \\ 志 澤 一 $之^{* * *}$ 高 橋 邦 弘***

\section{Microscopic Expressions of Stress and Higher-Order Stresses in Metals Based on Lattice Dynamics}

\author{
by \\ Yoshihiro YASUI ${ }^{*}$, Kenshin YASUI ${ }^{* *}$, Kazuyuki ShizAWA ${ }^{* * *}$, \\ and Kunihiro TAKAHASHI ${ }^{* * *}$
}

\begin{abstract}
The essence of macroscopic quantities in solid mechanics can be grasped by expressing these quantities with kinematic and mechanical quantities of atoms. In this paper, a method is proposed to obtain the microscopic expressions of macroscopic quantities. The concept of mesodomain is introduced in macroscopic materials so that the kinematic and mechanical quantities of atoms are averaged in this domain. The domains are associated with these averaged values and are regarded as infinitesimal elements of continua.Macroscopic balance equations and boundary conditions not only for stress but also for higher-order stresses are derived by using the principle of virtual power described with the above averaged values. The stress and higher-order stresses are expressed with the microscopic quantities which can be obtained from the molecular dynamics.
\end{abstract}

Key words : Solid mechanics, Higher-order stress, Lattice dynamics, Atom, Mesodomain, Balance equations, Molecular dynamics

\section{1 緒言}

\section{$1 \cdot 1$ 目的}

通常, 材料の巨視的な力学的特性は固体力学で用いら れる応力等の巨視的量により評価される。 しかし，材料 を構成するのは原子あるいは分子であるため, 当然, 巨 視的量はこれらの運動等に起因したものである.したが って，巨視的量の本質を理解するためには，これらの巨 視的量と原子や分子などの微視的量の関係を知ることが 重要であり, さらにこのことは, 材料設計等に新たな知 見を与えるものとなる。

また，材料固有のメゾスケールの構造も材料の特性に 対して大きな影響を及ぼす、特に，破壊現象や複雑な内 部構造を有する材料の特性を考える場合には，これを考 慮に入れる必要がある。材料の特性をさらに厳密に扱打 うとするならば, 高次の変形扣よびそれに対応した偶応 力等の高次の応力 ${ }^{1) ~ 4)}$ を考光る必要がある. な扔, 一般 に, 高次の応力とは応力こう配がある際に生じるもので あり, 特に応力こう配が大きいときに, その考慮が必要 となる.

近年，計算機シミュレーション ${ }^{5}$ による原子および分 子レベルの解析が, 各分野で盛んに行われている.この ような計算機シミュレーションで得られた計算結果から 巨視的量である応力等の值を求める際，巨視的量と微視
的量を結びつける関係式が必要となる。

これまでに，巨視的量を原子や分子の諸量で表現する ための研究 ${ }^{(6)}$ (7)がいくつか行われており, 応力, 内部工 ネルギーおよび熱流束等については, 关の微視的表現が すでに得られている。しかし, 高次応力に対する微視的 表現に関しては, その検討を行った研究は見あたらない。

そこで，本報ではメゾ領域の概念を用いた固体のモデ 儿を考元, 応力および高次応力を, 原子の速度などを用 いて微視的に表現することを目的とする。本モデルは， 物体をあくまでも原子の集合体とみなし，物体内にメゾ 領域を考え，さらにこの領域を連続体の物質点とみなす ことで, 連続体へと帰着させたものである。な打, 本研 究ではメゾ領域を物体の全体積に対しては1点とみなせ るほど小さいが，その中には多数の原子を含むような領 域であると考える.

このモデルを用いて，まず，仮想仕事率の原理を定式 化し，巨視的な力学的釣合い方程式扔よび境界条件を微 視的量により表現する。そ穴の際メゾ領域が変形の自由度 を有することから，この自由度に対応する力学的釣合い 方程式抢よび境界条件の微視的表現も同時に得ることが できる.さらにこれらより, 応力拉よび高次応力がどの ような微視的諸量により表現されるかを示す，また，高 次応力の微視的表現を用いて, 分子動力学 (MD) シミ 
ユレーションにより得られた原子の速度等から実際に高 次応力を求め, 本理論の妥当性を検討することにより, 本微視的表現が MD シミュレーションの結果を整理す るのに有用であることを示す。

\section{$1 \cdot 2$ 本報の記述内容と既報の内容との関係}

本報に関係した著者らの既報論文がいくつか公刊され ているが，それらと本報との関係を以下に示す。

本論文に関係する著者らの公刊論文は文献 8)１1) で ある.この内, 文献 10), 11）は極性物質に関する研究 であるため, 特殊な材料を対象にしている. 本論文のよ うに一般の材料を対象にした著者らによる研究には, 文 献 8)，9）がある.

文献 8) は, 熱的な検討, 特にエネルギー保存則（エネ ルギー方程式）を微視的に検討することを目的としてい る.また文献 9) は, 熱流束の微視的表現について詳細な 考察を加えたものであり，いずれの論文も熱的な諸量に関 する検討を行ったものである。これらの論文においては， 力学的な諸量に関する検討を目的としてはいないので, こ れら力学的諸量に関しては議論の中で必要となる最小限 の結果のみを示している. 実際, 文献 8)においてはその 2 章において，運動量保存則からの帰結として

(a) 力の鈞合い方程式 (支献 8), 式 (16))

(b) 高次応力の釣合い方程式（文献 8), 式 (17))

について示しているが, 最終結果のみを境界条件と共に 表示するに留まっている。同時に次の量の微視的表現に ついても結果のみを示しており，その表現に至る論拠に ついては触れなかった。

(c) 応力の微視的表現 (文献 8), 式 (18))

(d) 高次応力の微視的表現（文献 8), 式 (17) の括弧内) 文献 9) においてもその 2 章で同一の内容を, やはり結 果のみについて表示している. すなわち上記 (a)〜 (d)‘ 関する式は各々, 文献 9) の式 (7), (11)，(10) および式 （11）（式（11）の括弧内）において結果のみが表示され ている.

本論文はこれら (a)〜 (d) の結果の導出過程を与える ものである、これら既報の文献においては, 結果のみを 示した上記の全箇所で, その導出については別報による ことを明示しており，いわば前報 8)，9）で留保されて いた上記 (a)〜 (d) に関する力学的諸関係の導出過程を, 本報において初めて明らかにしようとするものである。以 下本報に打いては上記の (a)，(b) の導出過程を 3 章に打 いて, また (c), (d) の結果を導く論旨を 4 章に执いて記 述する。

\section{2 メゾ領域における運動学}

本理論に関する基本的な記述方法は前報 ${ }^{8), 9)}$ と同様で あるが, 2 章においてその概要をまとめておく.

\section{$2 \cdot 1$ 原子およびメゾ領域の運動}

Fig. 1 に示すように, メゾ領域内の $n$ 番目原子への位

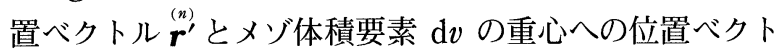
ル $\boldsymbol{r}$ の関係は,

$$
\stackrel{(n)}{r^{\prime}}=r+\stackrel{(n)}{\xi}
$$

のように表される. なお, $\stackrel{(n)}{\xi}$ はメゾ領域の重心から $n$ 番 目原子へ向かうべクトルである. また，本報では $\boldsymbol{r}^{\prime} に$ にお ける原子の諸量には全ていを付し，はなしの量は全てメゾ 領域内の平均量を表すものとする.

次に,メゾ領域内の任意の $n$ 番目原子に対する運動 学量 $\stackrel{(n)}{A^{\prime}}$ は, その平均量 $A$ と変動量 $\stackrel{(\widetilde{n})}{A^{\prime}}$ により以下のよう に表すことができる。

$$
\stackrel{(n)}{A^{\prime}}=A+\stackrel{(n)}{A^{\prime}}
$$

ここで， $\stackrel{(n)}{A^{\prime}}$ は, 任意のスカラー, ベクトルおよびテン

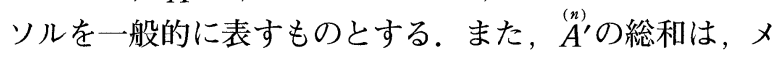
ゾ領域内の原子の総数を $N$ とすれば, 以下のように整 理できる.

$$
\sum_{n=1}^{N} \stackrel{(n)}{A^{\prime}}=\sum_{n=1}^{N} A+\sum_{n=1}^{N} \stackrel{(\widetilde{n})}{A^{\prime}}=\sum_{n=1}^{N} A=N A
$$

式 (3) では変動量の総和が零となること, すなわち

$$
\sum_{n=1}^{N} \stackrel{(\vec{n})}{A^{\prime}}=\mathrm{O}
$$

を用いた。 また， $\stackrel{(n)}{A^{\prime}}, A$ お $A$ おび $\stackrel{(\tilde{n})}{A^{\prime}}$ の変形前 $\left(t=\tau_{0}\right)$ の位置を固定した時間微分（物質時間微分）を以下のよ うに定義する。

$$
\left.\begin{array}{l}
\stackrel{(n)}{A^{\prime}} \equiv\left(\frac{\partial \stackrel{(n)}{A}^{\prime}}{\partial t}\right)_{\boldsymbol{R}}, \stackrel{(n)}{\Xi} \\
\dot{A} \equiv\left(\frac{\partial A}{\partial t}\right)_{\boldsymbol{R}} \\
\dot{(\vec{n})} \\
A^{\prime} \equiv\left(\frac{\partial \stackrel{(n)}{A}^{\prime}}{\partial t}\right)_{\boldsymbol{R}, \stackrel{(n)}{\Xi}}
\end{array}\right\}
$$

ただし，式 (5) で（）の右下に付した量は固定した量を 意味する。ささらに, $\boldsymbol{R}$ お゙よび 配置の位置を表し，これらは変形後 $(t=\tau)$ である現配置 の位置 $\boldsymbol{r}$ およびそととそれぞれ対応する，なお，本報で はべクトルおよびテンソルの直接表示を太字で表し, そ の成分を指標を伴う記号で表すものとする.

また, $\sum_{n=1}^{N} \stackrel{(\dot{n})}{A^{\prime}}$ と $\left(\sum_{n=1}^{N} \stackrel{(n)}{A^{\prime}}\right)^{\bullet}$ の関係は, 以下のとおりである.

$$
\sum_{n=1}^{N} \stackrel{(\dot{n})}{A^{\prime}}=\left(\sum_{n=1}^{N} \stackrel{(n)}{A^{\prime}}\right)^{\bullet}
$$

\section{$2 \cdot 2$ 原子の運動学量および力学量の平均化}

メゾ領域内での体積平均とメゾ領域表面での面積平均 を以下のように定義する.

$$
\begin{aligned}
& <\stackrel{(n)}{A^{\prime}}>_{v} \mathrm{~d} v \equiv \sum_{n=1}^{N} \stackrel{(n)}{A^{\prime}} \\
& <\stackrel{(n)}{A^{\prime}}>_{a} \mathrm{~d} a \equiv \sum_{n=1}^{M} \stackrel{(n)}{A^{\prime}}
\end{aligned}
$$

ただし, $\mathrm{d} v$ はメゾ要素の体積, $\mathrm{d} a$ はメゾ領域表面のあ る 1 つの面積要素の面積である. また $\mathrm{d} a$ 上には原子が $M$ 個存在するものとし,$\sum_{n=1}^{M} \stackrel{(n)}{A^{\prime}}$ はその面積要素上の原子 にわたる総和である．次に, $\mathrm{d} v$ 内の原子にわたる総和 および $\mathrm{d} a$ 上の原子にわたる総和に対して，それぞれそ の原子の個数による平均を, 以下のように定義する. 


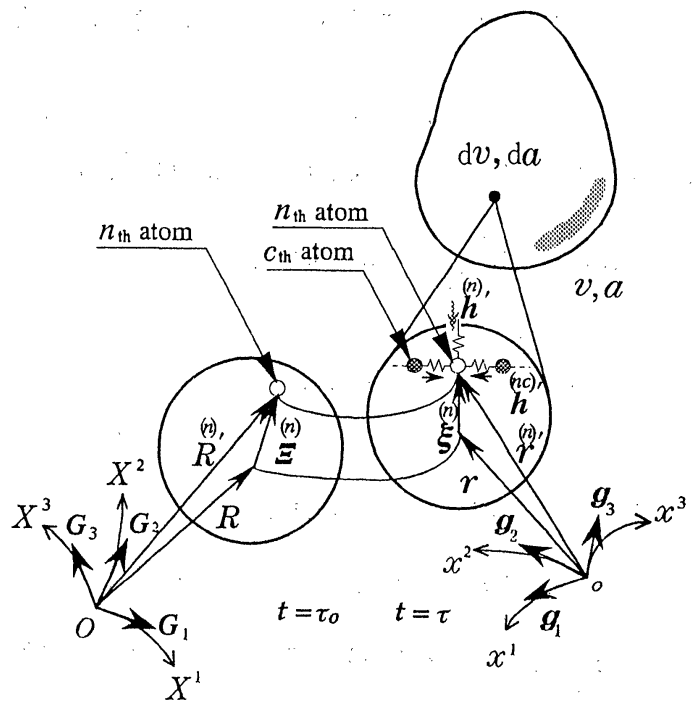

Fig. 1. Mesodomain.

$$
\begin{aligned}
& <A^{(n)}>N N \equiv \sum_{n=1}^{N} A^{(n)} \\
& <\stackrel{(n)}{A^{\prime}}>M M \equiv \sum_{n=1}^{M}{ }^{\prime(n)}
\end{aligned}
$$

\section{2・3 離散量の連続量への帰着}

原子の運動学量 $\stackrel{(n)}{A}$ は離散量であるため, 最小二乗法 を用いた回帰分析によって連続量に帰着させ，さらに平 均量を用いて書き改めると， $\stackrel{(n)}{A}$ は以下のようになる。

$$
\begin{aligned}
& \stackrel{(n)}{A^{\prime}}=\left\langle\stackrel{(n)}{A^{\prime}}\right\rangle_{N}+<\stackrel{(n)}{A^{\prime}},{ }_{i^{\prime}}>N \quad \stackrel{(n)}{\xi^{i}}+<\stackrel{(n)}{A^{\prime},{ }_{i j^{\prime}}>_{N}}{ }_{N}^{[2]} P^{i j} \\
& +\cdots+<\stackrel{(n)}{A^{\prime}, j_{1 j} j_{2} \cdots j_{s}^{\prime}}>_{N} \stackrel{[s]}{P^{j_{1} j_{2} \cdots j_{s}}}+\ldots
\end{aligned}
$$

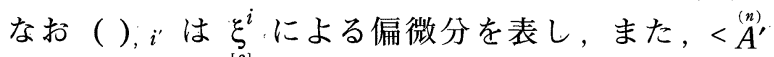

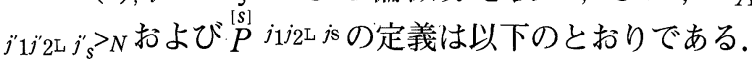

$$
\begin{aligned}
& <\stackrel{(n)}{A^{\prime}, j_{1}^{j} j_{2}^{\prime} \cdots j_{s}^{\prime}}>_{N} \boldsymbol{g}^{j_{1}} \otimes \cdots \otimes \boldsymbol{g}^{j_{s}} \equiv \operatorname{grad}^{[s]}<\stackrel{(n)}{A^{\prime}}>_{N} \\
& \stackrel{[s]}{P}_{j_{1} j_{2} \ldots j_{s}} \equiv \frac{1}{s !}\left(\xi^{n_{1}} \ldots \xi^{(n)}\right. \\
& \left.-\sum_{k=2}^{s-1} C_{s-k} \stackrel{[s-k] j_{1} \cdots j_{(s-k)}}{P} J^{[k]} j_{(s-k+1)}{ }^{\cdots j_{s}}-\stackrel{[s]}{J}^{j_{1} \cdots j_{s}}\right)
\end{aligned}
$$

ただし, $\operatorname{grad}^{\prime}$ は $\xi$ にるこう配を表し, $\operatorname{grad}^{(s)}$ はs $s$ 階の こう配である。 また， $\boldsymbol{g}$ は基底べクトルであり ${ }_{s} C_{s-k}$ は 2 項係数を表す。さらに，Jは当はメ゙領域の $k$ 次のモーメン 卜を表すものとし， $\xi$ の $k$ 個のテンソル積の平均として

$$
\stackrel{[k]}{\boldsymbol{J}} \equiv\langle\stackrel{(n)}{\boldsymbol{\xi}} \otimes \cdots \otimes \stackrel{(n)}{\boldsymbol{\xi}}\rangle_{N}
$$

にて定義される。ここで，計算の容易化扰よび論旨の単 純化を図るため，メゾ領域内の微視的こう配の平均は, 巨視的量 (平均量) の巨視的こう配に等しいという仮定 ${ }^{12)}$ (こう配拘束の仮定) を導入する.

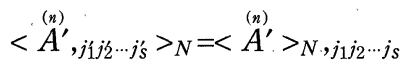

なお，式 (15) 左辺の（），iは $r^{i}$ による偏微分を表し，そ の定義は以下のとおりである.

$$
\left.<\stackrel{(n)}{A^{\prime}}\right\rangle_{N, j_{1} j_{2} \cdots j_{s}} \boldsymbol{g}^{j_{1}} \otimes \cdots \otimes \boldsymbol{g}^{j_{S}} \equiv \operatorname{grad}<\stackrel{(n)}{A^{\prime}}>_{N}
$$

こう配拘束の仮定を式 (11) に用いれば，次式を得る.

$$
\begin{aligned}
& \stackrel{(n)}{A^{\prime}}=\left\langle\stackrel{(n)}{A^{\prime}}\right\rangle_{N}+\left\langle\stackrel{(n)}{A^{\prime}}\right\rangle_{N, i}{ }^{(n)} \xi^{i}+\left\langle\stackrel{(n)}{A^{\prime}}\right\rangle_{N, i j}{ }^{[2]} P^{i j}
\end{aligned}
$$

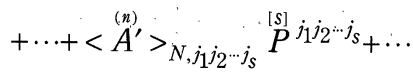

\section{3 力学的釣合い方程式および境界条件}

前報 ${ }^{8), 9)}$ では, 巨視的な力学的釣合い方程式および境 界条件の微視的表現にういて，只の結果のみを示して拧 いた．前報の目的である熱力学的な検討に対する準備と して，これらの結果を必要としたからである。これらの 結果に至る過程は，前報では留保しておいたが，本章で その導出を初めて行うことになる。

\section{$3 \cdot 1$ 原子の運動方程式}

Fig. 1 に示すようにメゾ体積要素 $\mathrm{d} v$ 内の $n$ 番目原子が, メゾ領域の表面外部から受ける力を $\boldsymbol{h}^{(n)}$ とする。 また， $n$ 番目原子に $\mathrm{d} v$ 内部で隣接する原子を $c$ 番目原子とし，

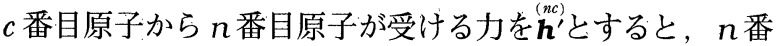
目原子が $\mathrm{d} v$ 内部で受ける力は $\sum_{c}^{(n)} \boldsymbol{h}^{\prime} と$ 書ける. 隣接する

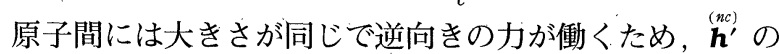
$\mathrm{d} v$ 内に打ける総和 $\sum_{n=1}^{N} \sum_{c} \boldsymbol{h}^{(n)}$ は零となる。 また, 原子の質量 を $m^{\prime}$ ，原子に作用する物体力を $\boldsymbol{f}^{\prime}$ とする。 ここでは単一 原子より構成されている物体を考え， $m^{\prime}$ は原子によらず一 定とし; また物体力 $\boldsymbol{f}^{\prime}$ も一定とする。 以上より, $\mathrm{d} v$ 内部 の $n$ 番目原子に対する運動方程式は次のようになる。

$$
m^{\prime} \boldsymbol{v}^{\prime(\dot{n})}=\boldsymbol{h}^{\prime}+\sum_{C}^{(n)} \boldsymbol{h}^{\prime \prime}+m^{\prime} \boldsymbol{f}^{\prime}
$$

\section{$3 \cdot 2$ 仮想仕事率の原理}

本節では，原子に対する運動方程式に，原子の仮想速 度 $\boldsymbol{v}^{\prime}$ を内積してメゾ領域にわたって和をとり，さらに物 体全体にわたり積分すれば，平均量によって表された仮 想仕事率の原理が以下のように定式化される.

$$
\begin{aligned}
\int_{v}<m^{\prime} & \left.v^{\prime} \cdot v^{\prime}\right\rangle_{v} \mathrm{~d} v=\int_{a}\left\langle\hat{h^{\prime}} \cdot \stackrel{(n)}{v^{\prime}}\right\rangle_{a} \mathrm{~d} a \\
+\int_{v} & \left\langle\boldsymbol{h}^{\prime} \cdot v^{\prime}\right\rangle_{v} \mathrm{~d} v+\int_{v}\left\langle m^{\prime} \boldsymbol{f}^{\prime} \cdot \widehat{(n)} v^{\prime}\right\rangle_{v} \mathrm{~d} v
\end{aligned}
$$

ここで; 原子の仮想速度を $\boldsymbol{v}^{\prime}$ メゾ体積要素の重心の仮

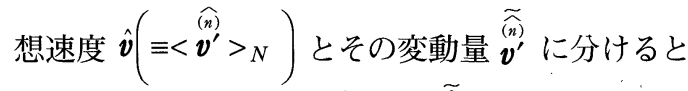

$$
\widehat{(n)} \boldsymbol{v}^{\prime}=\hat{\boldsymbol{v}}+\stackrel{\widetilde{(n)}}{\boldsymbol{v}^{\prime}}
$$

のようになる，次に式 (19) の各項における原子の仮想 速度に式 (20) を代入する。まず, 式 (19) の左辺は,

$$
\begin{aligned}
& \int_{v}\left\langle m^{\prime} \boldsymbol{( n v}^{\prime} \cdot \widehat{(n)} \boldsymbol{v}^{\prime}\right\rangle_{v} \mathrm{~d} v \\
& \left.=\int_{v}<m^{\prime}(\dot{\boldsymbol{v}}+\dot{\overline{(\vec{n})}}) \cdot(\hat{\boldsymbol{v}}+\widetilde{\widehat{(\hat{n}})}) \boldsymbol{v}^{\prime}\right){ }_{v} \mathrm{~d} v \\
& =\int_{v}<m^{\prime} \dot{\boldsymbol{v}} \cdot \hat{\boldsymbol{v}}>_{v} \mathrm{~d} v+\int_{v}\left\langle m^{\prime} \dot{\boldsymbol{v}} \cdot \boldsymbol{v}^{\widetilde{\widetilde{(n)}}}\right\rangle_{v} \mathrm{~d} v \\
& +\int_{v}<m^{\prime} \boldsymbol{v}^{\prime} \cdot \hat{\boldsymbol{v}}>_{v} \mathrm{~d} v+\int_{v}<m^{\prime} \frac{\dot{(\vec{n})}}{\boldsymbol{v}^{\prime} \cdot \boldsymbol{v}^{\prime}}>_{v} \mathrm{~d} v \\
& =\int_{v}<m^{\prime}>_{v} \dot{\boldsymbol{v}} \cdot \hat{\boldsymbol{v}} \mathrm{d} v+\int_{v}\left\langle m^{\prime} \frac{\dot{(\vec{n})}}{\boldsymbol{v}^{\prime} \cdot \boldsymbol{v}^{\prime}>_{v}} \mathrm{~d} v\right.
\end{aligned}
$$

となる．ただし，上式 (21) の第 3 辺の第 2,3 項は式 (4) より零である.また, 式 (19) の右辺第 2 項は, 


$$
\begin{aligned}
& \int_{v}\left\langle\boldsymbol{h}^{\prime(n)} \cdot \widehat{(\hat{n})} \boldsymbol{v}^{\prime}\right\rangle_{v} \mathrm{~d} v \\
& =\int_{v}\left\langle\boldsymbol{h}^{\prime}\right\rangle_{v} \cdot \hat{\boldsymbol{v}} \mathrm{d} v+\int_{v}\left\langle\boldsymbol{h}^{\prime} \cdot \boldsymbol{v}^{\prime}\right\rangle_{v} \mathrm{~d} v \\
& =\int_{v}\left\langle\boldsymbol{h}^{\prime} \cdot \boldsymbol{v}^{\prime(n)}\right\rangle_{v} \mathrm{~d} v
\end{aligned}
$$

となる.なお, $\left\langle\boldsymbol{h}^{(n)}>_{v}\right.$ は $\sum_{n=1}^{N} \sum_{c} h_{\boldsymbol{h}^{\prime}}^{(n c)}=0$ より零であり, こ のことから式 (22) の第 2 辺の第 1 項も零である.ささに 式 (19) の右辺第 3 項も同様にして,

$$
\begin{aligned}
& \left.\int_{v}<m^{\prime} \boldsymbol{f}^{\prime} \cdot \boldsymbol{v}^{\prime}\right\rangle_{v} \mathrm{~d} v \\
& =\int_{v}<m^{\prime} \boldsymbol{f}^{\prime}>_{v} \cdot \hat{\boldsymbol{v}} \mathrm{d} v+\int_{v}<m^{\prime} \boldsymbol{f}^{\prime} \cdot \widetilde{\widehat{(n)}} \\
& =\int_{v}<m^{\prime}>_{v} \mathrm{~d} \boldsymbol{f} \cdot \hat{\boldsymbol{v}} \mathrm{d} v
\end{aligned}
$$

となる.ここで, $m^{\prime} \boldsymbol{f}^{\prime}$ は一定であるため, 式 (23) の第 2 辺の第 2 項も式 (4) の結果が用いられている.

式 (21)～(23) より，仮想仕事率の原理を表す式 (19) は次式のように整理できる.

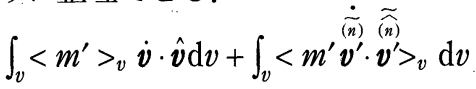

$$
\begin{aligned}
& =\int_{a}\left\langle\boldsymbol{h}^{\prime}\right\rangle_{a} \cdot \hat{\boldsymbol{v}} \mathrm{d} a+\int_{a}\left\langle\boldsymbol{( n )}^{(\boldsymbol{n})} \cdot \underset{\hat{(n)}}{\widetilde{\boldsymbol{v}^{\prime}}}\right\rangle_{a} \mathrm{~d} a \\
& =\int_{v}\left\langle\boldsymbol{h}^{\prime(n)} \cdot \underset{\boldsymbol{v}^{\prime}}{\widetilde{(\hat{)})}}\right\rangle_{v} \mathrm{~d} v+\int_{v}<m^{\prime}>_{v} \boldsymbol{f} \cdot \hat{\boldsymbol{v}} \mathrm{d} v
\end{aligned}
$$

次に原子の仮想速度を式 (17) を用いて級数展開すれば

$$
\begin{aligned}
& {\stackrel{(n)}{v^{\prime}}}^{i}=\hat{v}^{i}+\left.\hat{v}^{i}\right|_{i} \stackrel{(n)}{\xi}^{j}+\left.\hat{v}^{i}\right|_{j k} P^{[2]} \\
& +\cdots+\left.\hat{v}^{i}\right|_{j_{1} \cdots j_{s}} \stackrel{|s|}{P} j_{1} \cdots j_{s}+\cdots
\end{aligned}
$$

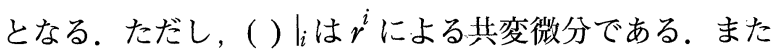
式 (20) と式 (25) を比較することにより，仮想速度の変 動量は, 式 (25) の級数展開の第 2 項以後として以下のよ うに表すことができる。

$$
\stackrel{\widetilde{(n)}}{\widetilde{v^{\prime}}}=\left.\hat{v}^{i}\right|_{j} \stackrel{(n)}{\xi^{j}}+\left.\hat{v}^{i}\right|_{j k} \stackrel{[2]}{P}{ }^{j k}+\cdots+\left.\hat{v}^{i}\right|_{j_{1} \cdots j_{s}} \stackrel{[s]}{P} j_{1} \cdots j_{s}+\cdots
$$

式 (26) を式 (24) に代入すれば，次式を得る.

$$
\begin{aligned}
& \int_{v}\left\{\hat{v} \cdot<m^{\prime}>_{v} \dot{v}+\cdots\right. \\
& \left.+\operatorname{grad} \hat{v} \cdot\left\langle m^{\prime} v^{(\dot{n})} \otimes \stackrel{[t]}{\boldsymbol{P}}\right\rangle_{v}+\cdots\right\} \mathrm{d} v \\
& =\int_{a}\left\{\hat{\boldsymbol{v}} \cdot\left\langle\stackrel{(n)}{\boldsymbol{h}^{\prime}}\right\rangle_{a}+\cdots\right. \\
& \left.+\operatorname{grad} \hat{v} \cdot\left\langle\boldsymbol{h}^{\prime} \otimes \stackrel{[t]}{\boldsymbol{P}}\right\rangle_{a}+\cdots\right\} \mathrm{d} a \\
& +\int_{v}\left\{\operatorname{grad} \hat{v} \cdot\left\langle\boldsymbol{h}^{\prime} \otimes \stackrel{(n)}{\xi}\right\rangle_{v}+\cdots\right. \\
& \begin{array}{c}
\left.+\operatorname{grad} \hat{v} \cdot\left\langle\boldsymbol{h}^{[n c)} \otimes \stackrel{[t]}{\boldsymbol{P}}\right\rangle_{v}+\cdots\right\} \mathrm{d} v \\
+\int_{v} \hat{v} \cdot\left\langle m^{\prime}>_{v} \boldsymbol{f} \mathrm{d} v\right.
\end{array}
\end{aligned}
$$

式 (27) の右辺の 2 つ目の積分を部分積分し, Gaussの発 散定理を用いて整理すれば，仮想速度の任意性より次の ような巨視的な力学的釣合い方程式ならびに境界条件の 微視的表現が得られる。 まず，体積 $v$ 内における.運動量 方程式が次のように得られる。

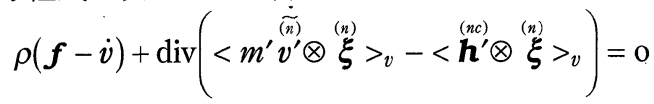

なお， $\rho$ はメゾ領域の密度であり，その定義は以下のと おりである。

$$
\rho \equiv<m^{\prime}>_{v}
$$

高次量に対する釣合い方程式も以下のように得られる.

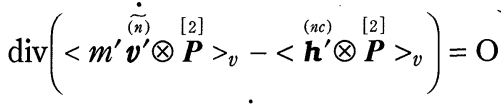

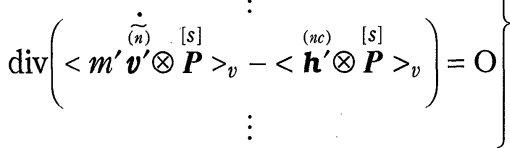

また，面積 $a$ 上における境界条件は，

$$
\left.<\boldsymbol{h}^{\prime}>_{a}=\left(\left\langle m^{\prime} \stackrel{\dot{\tilde{n}})}{v^{\prime} \otimes} \stackrel{(n)}{\xi}\right\rangle_{v}-<\boldsymbol{h}^{\prime} \otimes \stackrel{(n)}{\xi}\right\rangle_{v}\right) n
$$

となり，高次量に対する境界条件も，以下のように得ら れる。

$$
\begin{aligned}
& <\boldsymbol{h}^{\prime} \otimes \stackrel{(n)}{\xi}>_{a} \\
& =\left(\left\langle m^{\prime} \boldsymbol{v}^{\dot{\tilde{n}}} \otimes\left[{ }^{[2]}\right\rangle_{v}-\left\langle\dot{h}^{\prime(n c)} \otimes \stackrel{[2]}{P}\right\rangle_{v}\right) \boldsymbol{n}\right. \\
& \left\langle\stackrel{(n)}{\boldsymbol{h}^{\prime} \otimes} \stackrel{[s-1]}{\boldsymbol{P}}\right\rangle_{a} \\
& \left.\left.=\left(\begin{array}{c}
\dot{\overline{(n)}}\left[\stackrel{[s]}{\boldsymbol{v}^{\prime} \otimes}\right\rangle_{v}-\left\langle\boldsymbol{h}^{\prime} \otimes[s]\right. \\
\vdots
\end{array}\right) \boldsymbol{n}\right\rangle_{v}\right)
\end{aligned}
$$

\section{4 応力および高次応力の表現}

前報 ${ }^{8), 9)}$ では, 応力および高次応力の微視的表現につ いては，前報の主たる目的ではないので，結果のみを示 しておいた．その表現に対する論拠は別報に委ねるとし てきたが，本章でその論理過程を明らかにする.

\section{$4 \cdot 1$ Cauchy 応力}

本節では，式 (31) の巨視的な境界条件の微視的表現 と従来からよく知られている巨視的な境界条件を比較す ることにより, Cauchy の応力テンソル $\boldsymbol{T}$ を微視的に表 現する。まず，従来からよく知られている巨視的な運動 方程式および境界条件を以下に示す。

$$
\begin{gathered}
\rho(\boldsymbol{f}-\dot{\boldsymbol{v}})+\operatorname{div} \mathbf{T}=0 \\
\stackrel{(n)}{\boldsymbol{t}}=\boldsymbol{T} \boldsymbol{n}
\end{gathered}
$$

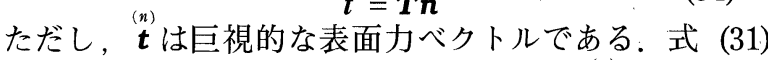
と式 (34) を比較すれば，表面力べクトル $\boldsymbol{t}^{(n)}$ 打よび応力 テンソル $\boldsymbol{T}$ は次のように微視的に表現できる.

$$
\begin{aligned}
& \stackrel{(n)}{\boldsymbol{t}}=\left\langle\stackrel{(n)}{\boldsymbol{h}}^{\prime}\right\rangle_{a} \\
& \mathbf{T}=\left\langle m^{\prime} \dot{v}^{\prime} \otimes \stackrel{(n)}{\xi}>_{v}-<\stackrel{(n c)}{\boldsymbol{h}^{\prime}} \otimes \stackrel{(n)}{\xi^{\prime}}>_{v}\right.
\end{aligned}
$$

また, 式 (36) の応力テンソルの微視的表現は式 (28) と 式 (33) を比較することによっても同様に得られる.さら に, 式 (36) は定常状態を仮定し, 長時間平均すれば,

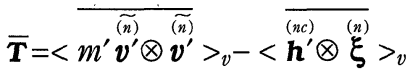

と変形することもできる. ${ }^{7)} お, \overline{(\quad)}$ は，長時間平 均を表す。 


\section{$4 \cdot 2$ 高次応力}

前章で得られた式 (30) および式 (32) は, 高次の変形 に対する巨視的な力学的釣合い方程式および境界条件で あり，高次応力の項を含んでいる。ここで，式 (31) の Cauchy 応力に対する境界条件と式 (32) の高次量に対す る境界条件を比較すれば，その類似性より式 (32) の右 辺の（）内が高次応力であることが分かる．例として $s$ 次の高次応力 $\stackrel{(s)}{\mathbf{T}}$ いいて, その微視的表現 $(38)$, およ び釣合い方程式 (39) と境界条件 (40) の微視的表現を以 下に示す。

$$
\begin{aligned}
& \stackrel{(s)}{\boldsymbol{T}}=\left\langle m^{\prime} \stackrel{\dot{(n)}}{\boldsymbol{v}^{\prime}} \otimes \stackrel{[s]}{\boldsymbol{P}}\right\rangle_{v}-\left\langle\stackrel{(n c)}{\boldsymbol{h}^{\prime}} \otimes \stackrel{[s]}{\boldsymbol{P}}\right\rangle_{v}
\end{aligned}
$$

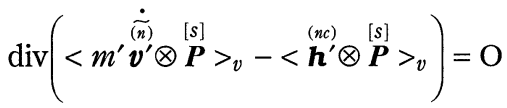

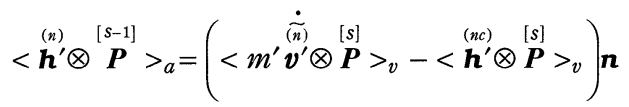

ただし, $\left\langle\stackrel{(n)}{\boldsymbol{h}^{\prime}} \otimes \stackrel{[s-1]}{\boldsymbol{P}}\right\rangle_{a}$ は $s$ 次の表面力テンソルを表 す.また，式 (38) より高次応力とは微視的には原子の 慣性力 $m^{\prime} \underset{\boldsymbol{v}^{\prime}}{\mathbf{( n )}}$ およびメゾ領域内の原子間力 $\boldsymbol{h}^{\prime}$ の高次モー メントの体積平均であることがわかる，なお，式 (38) の 妥当性については次章で検討する.

\section{5 高次応力の微視的表現に対する検討}

本章では高次応力の中の 2 次応力を例にとり，その微 視的表現の妥当性を検討する。 また同時に本微視的表現 は MD シミュレーションの結果を整理するのに有用であ ることを示す. なお 2 次の応力テンソル ${ }^{[2]}$ の微視的表現 は，式 (38) により以下のように記述できる.

$$
\stackrel{(2)}{\boldsymbol{T}}=\left\langle m^{\prime} \boldsymbol{v}^{\prime} \otimes \stackrel{[2]}{\boldsymbol{P}}\right\rangle_{v}-\left\langle\stackrel{(n c)}{\boldsymbol{h}^{\prime} \otimes} \stackrel{[2]}{\boldsymbol{P}}\right\rangle_{v}
$$

極性体理論 $^{13)}$ によれば, 巨視的な 2 次応力の意味は, 要 素に働く内力による単位面積当たりの 1 次モーメントで ある.これに対して，式（41）の結果によれば，巨視的 な 2 次応力の微視的な意味は, 要素内の各原子に働く原 子間力および慣性力による単位体積当たりの 2 次モーメ ントである，本章ではこれらの物理的解釈に従い，同一 条件下でそれぞれ 2 次応力を計算し，この結果を比較検 討することで, ここで得られた 2 次応力の微視的表現の 妥当性について調べる.

\section{$5 \cdot 1$ 本理論に基づいた 2 次応力の計算}

まず, 本 2 次応力の微視的表現を用いて巨視的な 2 次 応力の值を計算する. 式 (41) を用いて2 次応力を計算す る場合, 原子の慣性力, 原子間力等が必要となる. そこ で，ここでは MD シミュレーションを行うことで，これ らの微視的量を計算し, その結果から 2 次応力を求める.

MD シミュレーションは Fig. 2 に示すような $10 \times 10 \times$ 10 の 1000 粒子モデルを用いて，Al を想定した解析を行 う。そこで初期の原子間距離は $286 \mathrm{pm}$ ，原子の質量は $4.48 \times 10^{-26} \mathrm{~kg}$ とする. また原子間のポテンシャル力 ${ }^{14), 15)}$ は線形ばねによるばね力とする。なお，その際のばね定 数 $K$ は $45.3 \mathrm{~N} / \mathrm{m}$ である.ここで高次応力とは, 応力こ

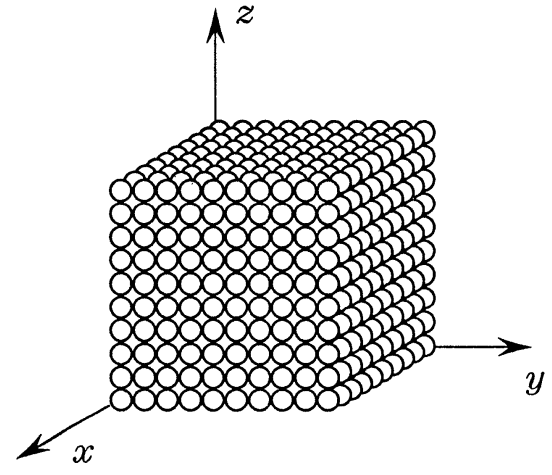

Fig. 2. Simulation model.

う配がある場合に生じるものであるため, 荷重は Fig. 3 のような $y$ 軸方向に直線的に変化するようなものを $z$ 面 に負荷する.ただし, 最大荷重となる $z$ 面両端の原子に

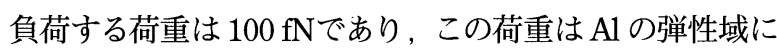
十分収まる大きさである。

以上の解析モデルと荷重条件のもとで実際に分子シミ ユレーションを行い, その結果, 得られた微視的量を式 (41) を用いて整理すると Fig. 4 のようになる. ただし，2 次応力は 27 個の成分をもつテンソルであるが, Fig. 4 は その中の 1 つである $T^{z y z}$ 成分についてその時間変化を表 したものである. また他の 26 個の成分も Fig. 4 と類似の 波形となる。なお，本シミュレーションは $1 \mathrm{fs}$ の時間ス テップで行い, 以下に示す 2 次応力の值は, $10 \mathrm{ps}$ で平均 したものである.

$$
\begin{aligned}
& \stackrel{[2]}{T}^{z y z}=26.2 \mu N / m \\
& \stackrel{[2]}{T}^{z z y}=26.2 \mu N / m \\
& \stackrel{[2]}{T}^{p q r}=7.65 \times 10^{-12} \sim 0.268 \simeq 0 \quad \mu N / m \\
& \text { (ただし }, T^{[2]} \neq T^{[2]} T^{[2 y z} T^{[2]} \text { ) }
\end{aligned}
$$

式 (44) の $T^{[2]}$ はr $T^{[2]}$ および $T^{[2]}$ 以外の 25 個の成分を表 す.また，これら 25 個の成分は $T^{[2 y z}, T^{[2]}$ に比べ，最も 大きいものでも $1 \%$ 程度であるため零として無視した

\section{$5 \cdot 2$ 極性体理論に基づいた 2 次応力の計算}

前節と同じ Fig. 3 の荷重条件のもとで極性体理論に基 づいて 2 次応力を計算する. 前述のように, 2 次応力の 物理的意味は各面に働く外力の 1 次モーメントの面積平 均である. 例えば $T^{x y z}$ 成分は $x$ 面に働く $y$ 方向の荷重と 要素の重心から作用点までの $z$ 方向のモーメントアーム による 1 次モーメントを $x$ 面の面積で割ったものである. な拉，各面に働く 1 次モーメントはその面上の原子に働 $<1$ 次モーメントの総和として求める. 以上の考えに従 って 2 次応力を計算すれば以下のようになる。

$$
\begin{aligned}
& \stackrel{[2]}{T}^{z y z}=29.7 \mu N / m \\
& \stackrel{[2]}{T}^{z z y}=28.6 \mu N / m \\
& \stackrel{[2]}{T}^{p q r}=0 \quad \mu N / m \\
& \left(\stackrel{[2]]}{T}^{p q r} \neq \stackrel{T}{[2]}^{z y z}, \stackrel{[2]}{ }^{z z y}\right)
\end{aligned}
$$

式 (42)〜 (44) と式 (45)〜（47）をそれぞれ比較すると， 本理論に基づいて得られた 2 次応力は，極性体理論に基 


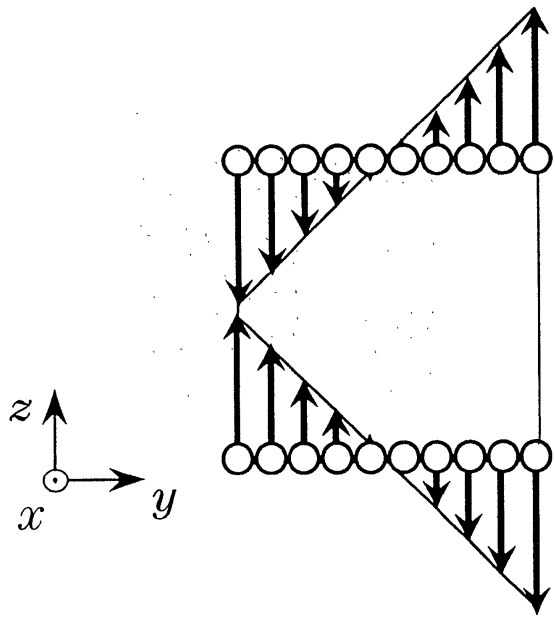

Fig. 3. Loading condition.
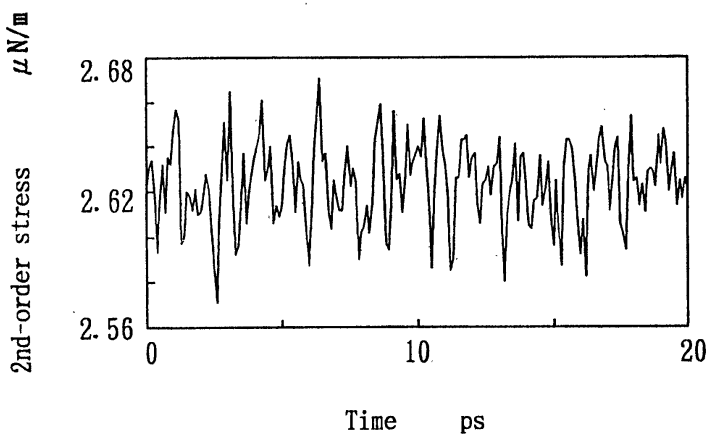

Fig. 4. 2nd-order stress.

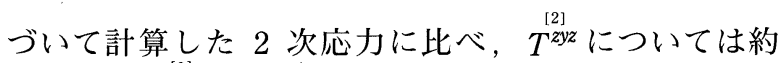
$11 \%$ ，またT $T^{2 z y}$ については約 $8 \%$ 小さく，元の他の成分 については誤差の範囲で一致した。

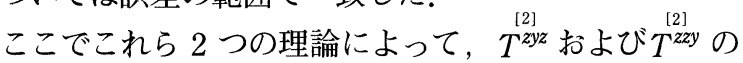
值が異なる理由について検討する。両理論では 2 次応力 をそれぞれ，原子に加わる 2 次モーメントの体積平均扔 よび原子に加わる 1 次モーメントの面積平均として計算 しているため，これらが一致するには，原子に加わる 2 次モーメントの総和が, 原子に加わる 1 次モーメントの 総和にメゾ領域の 1 辺の長さを乗じた大きさとなる必要 がある。しかし，実際には 2 次モーメントの総和は 1 次 モーメントの総和に 1 原子間距離だけ短い長さを乗じた 値となる.すなわち本モデルの場合, Fig. 5 に示すよう に,メゾ領域が原子間距離の 10 倍を 1 辺とする立方体 であるため, 2 次モーメントの総和は1次モーメントの総 和に原子間距離の 9 倍を乗じた大きさとなる。これよ り, 本理論に基づく 2 次応力は極性体理論に基づく 2 次 応力の $9 / 10$ 倍となり，両者の值に約 10\% 程度の差が生 ビたと考学られる。

なお，このように1原子間距離分の違いが生じるのは， Fig. 5 からわかるようにメゾ領域の境界が，メゾ領域内 で最も外側にある原子よりさらに半原子間距離だけ外側 にあるためである。すなわち，メゾ領域の体積およびそ の外表面の面積は，この境界を基に計算しているが，原 子に加わる 2 次打よび 1 次モーメントはモーメントアー

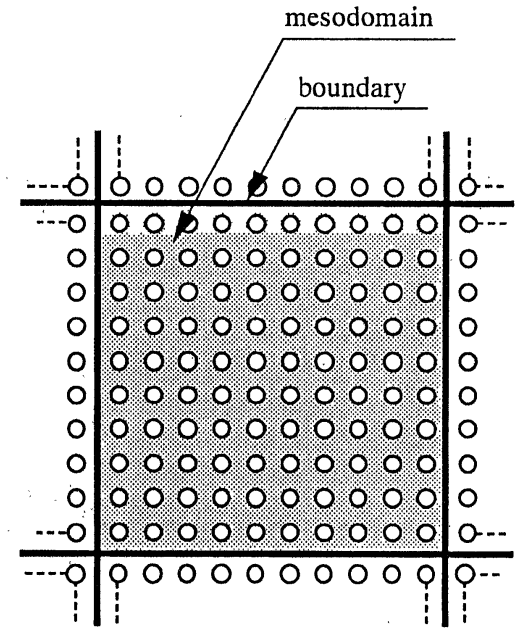

Fig. 5. Boundary of mesodomains.

ムである $\xi_{\xi}^{(n)}$ がメ゙領域の重心から原子へ向かう位置べク トルであるため, 各モーメントは境界より常に半原子間 距離短いモーメントアームを用いて計算していることに なる。そのためメゾ領域全体では，1 辺につき 1 原子間 距離の違いが生じると考えられる。そこで仮に，100× $\times 100 \times 100$ の 1000000 粒子モデルを用いて，1000 粒子 モデルと同様の計算を行ったとすれば，本理論に基づく 2 次応力は極性体理論に基づく 2 次応力の 99/100 倍とな り，両者の值は約 $1 \%$ 程度の差になると予想される。す なわち, シミュレーションモデルの粒子数を増やせば, これらの值の差は小さくなると考えられる.

以上の考察から本理論から導かれた 2 次応力の微視的 表現は妥当であり, さらに, 前節で示したように本表現 はMD シミュレーションの結果から巨視的量である 2 次 の応力を求めるのに有用である.

\section{6 結言}

著者らがこれまで検討を行ってきたメゾ領域の概念と その表示法を用いて，原子の運動をもとに，力学的釣合 い方程式を微視的な検討に基づき導出した。 また応力お よび高次応力の微視的な表現を原子の運動により与える ことができた。これらの結果は著者らによる既報に利用 されてはいるが，その導出は本論文によって初めて明ら かになったものであり, 本論文が前報を含めた一連の検 討の最も重要な基礎を与えることになる。 また，ここで 得られた諸式は, 分子シミュレーションの結果を整理す る際に，その有用性の高いことを確認した。これらの結 果をまとめると以下のとおりである.

(1)メゾ領域を導入することにより, 力学的釣合い方 程式ならびに境界条件を原子の運動に基づいて記述する ことができた。これらには高次応力に関する釣合い方程 式も含まれている.

(2) 巨視的力学的である応力ならびに高次応力の表現 を微視的な原子運動により表記することができた．これに より高次応力の微視的意味は, 原子の慣性力と原子間力 の高次モーメントの体積平均であることなどが判明した.

(3)ここで得られた微視的表現は, MD シミュレーシ 
ヨンの結果を巨視的な量へと整理する際に有用である.

ご討論頂いた本塾大学院の中根一起氏；藤沼宏之氏， 松崎 大氏ならびに本塾学部の藤原崇師氏に深謝する.

\section{参 考 文 献}

1) R. D. Mindlin, Arch. Rat. Mech. Anal., 16, 51 (1964).

2) R. D. Mindlin and H. F. Tiersten, Arch. Rat. Mech. Anal., 17, 415 (1964).

$3)$ R. A. Toupin, Arch. Rat. Mech. Anal., 17, 7 (1964).

4) I. A. Kunin, "Elastic Media with Microstructure II", p.122 (1983) Springer-Verlag.

5 ) G. Ciccotti, D. Frenkel and I. R. McDonald., "Simulation of Liquids and Solids", p.3 (1987) North-Holland.

6 ) J. H. Irving and J. G. Kirkwood., J. Chem. Phys., 18, 817 (1950).

7 ）小竹 進, “分子熱流体”, p.68（1990）丸善.
8 ）安井義博, 志澤一之, 高橋邦弘, 日本機械学会論文集, A62, 2116 (1996).

9 ) 安井義博, 志澤一之, 高橋邦弘, 日本機械学会論文集, A63, 595 (1997)

10）中根一起, 藤沼宏之, 志澤一之, 高橋邦弘, 日本機械学 会論文集，A-63，1096（1997）.

11）中根一起, 藤沼宏之, 志澤一之, 高橋邦弘, 日本機械学 会論文集，A-63，1104（1997）.

12）高橋邦弘, 応用数理, 5-2, 112 (1995).

13）大南正瑛, “マイクロメカニックス入門”, p.29（1980）オ - ム社.

14) J. H. Weiner, "Statistical Mechanics of Elasticity", p.127 (1983) John Wiley \& Sons.

15) A. Askar, "Lattice Dynamical Foundations of Continuum Theories", p.3 (1985) World Scientific. 